\title{
MULTIDIMENSIONAL PERSPECTIVE OF PERCEIVED VALUE IN INDUSTRIAL
}

\section{CLUSTERS}

LUIS J. CALLARISA FIOL, Universitat Jaume I of Castellón (Spain), Dept. of Business Administration and Marketing, callaris@emp.uji.es

MIGUEL A. MOLINER TENA, Universitat Jaume I of Castellón (Spain), Dept. of Business Administration and Marketing, amoliner@emp.ujji.es

JAVIER SÁNCHEZ GARCÍA, Universitat Jaume I of Castellón (Spain), Dept. of Business Administration and Marketing, jsanchez@emp.uji.es

August 2007

Send correspondence Luis J. Callarisa Fiol, Miguel A. Moliner, Dept. of Business Administration and Marketing, Universitat Jaume I de Castellón, Campus del Riu Sec, 12071 Castellón (Spain) (callaris@emp.uji.es), Tlf. 964387121 , Fax. 964728629 
MULTIDIMENSIONAL PERSPECTIVE OF PERCEIVED VALUE IN INDUSTRIAL CLUSTERS

\begin{abstract}
Purpose: This paper aims to demonstrate that aspects of a rational or functional character and aspects of an emotional and social nature condition the perceived value of the exchange relationships among firms in an industrial cluster.
\end{abstract}

Methodology/approach: The research uses Structural Equation Models (SEM) to test the models and applies the maximum likelihood estimation method in all the causal models obtained in the course of the data analysis.

Findings: The results obtained support the hypotheses put forward, and in particular the importance of emotional and social values in industrial relations.

Research limitations/implications: Recent advances in consumer and services marketing consider that perceived value and satisfaction are central to explaining customer loyalty. However, very few studies in B2B explain the perceive value multidimensionality. For this propose, the authors test their working hypotheses in the Spanish ceramic tiles cluster. Specifically, they analyze the relationships between manufacturers and a supplier of frits, enamels and ceramic colors and related services.

Practical implications: An empirical study demonstrates that experience and interpersonal relationships are more important than price and switching costs in an industrial cluster context. The empirical study and the results provide an importance evidence for managers: the critical influence of the Emotional and social perceived values by the customer on his level of satisfaction and on the achievement of final loyalty.

Originality/value of paper: The importance of the most intangibles dimensions of value for the industrial cluster relations between companies

Keywords: Perceived value, Spanish ceramic tiles cluster, functional value, emotional value, social value

This is a research paper. 


\section{Introduction}

The main objective of this paper is to demonstrate that aspects of a rational or functional character, together with other aspects of an emotional and social nature, have a determinant influence on the perceived value of the exchange relationships among firms within an industrial cluster. The authors put forward various working hypotheses and test them in the Spanish ceramic tiles cluster. Specifically, they analyze the relationships between manufacturers and a supplier of frits, enamels and ceramic colors and related services.

\section{Literature Review}

The relationships occurring in a cluster represent a competitive advantage for the firms located in these areas. The study of the relationships formed in this context is a crucial point of interest for industrial marketing. Interdependence and long-term relationships in B2B are matters of concern to marketing researchers (Ford and McDowell, 1999; Lapierre 2000; Eggert and Ulaga 2002; Barnes, 2003; Bonner and Calantone 2005; Spiteri and Dion 2004; Lindgreen and Wynstra, 2005, Ulaga and Eggert, 2003, 2006).

In this vein, we understand customer perceived value as a multidimensional construct. This perceived value encapsulates the overall assessment that a customer makes about the utility of a relationship with one or more suppliers of products and services. This assessment derives from the customer's perceptions of what he or she receives and gives and takes into account affective, emotional, social and rational or functional elements, all of which interact and influence each other to produce this final valuation.

\section{Perceived value in industrial clusters}

A key study in the conceptualization of perceived value is that of Sheth, Newman and Gross (1991a and 1991b) who, in a vast empirical multi-disciplinary study including economics, marketing and clinical and social psychology, identify five dimensions of perceived value: social, emotional, functional, epistemic and conditional.

The most important efforts to test this theoretical proposal are those of Sweeney, Soutar and Lester (1996) and Sweeney and Soutar (2001), who through different empirical studies design a scale of measurement of perceived value (PERVAL). The analyses of reliability and validity these authors carried out in designing PERVAL resulted in a reduction of the 5 dimensions proposed by Sheth, Newman and Gross (1991a and 1991b) to 3: functional, social and 
emotional, although they identify 3 types in the functional dimension (price, quality and versatility).

Most subsequent studies coincide in the identification of functional and emotional components (de Ruyter et al, 1997; Gwinner, Gremler and Bitner 1998; Henning-Thurau, Gwinner and Gremler 2002; Swenney and Soutar, 2001; Robinette, Brnad and Lenz 2001). In general, scholars tend to agree on the existence of at least three dimensions in perceived value: functional, social and emotional.

However, these studies focus on perceived value in consumer markets. Very few studies into the dimensionality of perceived value exist at industrial market level (Simon and Mandjack, 2004; Biggemann and Buttle, 2005; Lindgreen and Wynstra, 2005, Ulaga and Eggert, 2006). The literature review uncovers studies by Anderson, Jain and Chintagunta (1993): Ford and McDowell, (1999); Lapierre, (2000); laga and Chacour, 2001; Flint and Woodruff, 2001; Hogan (2001); Sharma, Krishnan and Grewal (2001); Eggert and Ulaga (2002) Ulaga and Eggert (2003 and 2006); Brenan, Turnbull and Wilson (2003), in which the dimensionality of value is present, but not in a single form. Nevertheless, as in consumer markets, the underlying dimensionality appears to rest on two factors, intangible and tangible factors. This study therefore follows, Newman, and Gross (1991b) and later Sweeney and Soutar (2001) and Eggert and Ulaga (2002) in differentiating between functional or cognitive dimensions, emotional or personal dimensions (Eggert and Ulaga 2002) and social dimensions (Lapierre 2000) with wholly intangible components, leading to the first hypothesis of the study:

$\mathrm{H}_{1}$ : Perceived value in an industrial market is a second order multidimensional construct comprising three dimensions: functional, social and emotional.

The first hypothesis considers perceived value to be a second order construct, implying that each dimension in turn comprises various sub-dimensions. The functional dimension of value is that relating to the utility derived from the attributes of the products and services. The industrial customer obtains value from attributes such as product quality, service quality, or price (Sweeney, Soutar and Johnson 1999). This is an economic and rational analysis comparing benefits and sacrifices, a concept that coincides with the view of perceived value that some authors hold (Lovelock 1991; Anderson, Jain and Chintagunta 1993; Cronin et al. 2000; Rust, Zeithmal and Lemmon 2000). This perspective identifies the quality of the product and services as positive values or benefits, and the price and other non-monetary sacrifices as negative values or sacrifices (Berry, Seider and Gresham 2002). The functional 
dimension is therefore almost an equivalent valuation to the quality/ price ratio, but with the inclusion of a non-monetary sacrifice component. The second hypothesis relating to the functional dimension is therefore:

$\mathrm{H}_{2}$ : The functional dimension of perceived value in an industrial market comprises a positive component (perceived quality) and a negative component (monetary and non-monetary).

The emotional dimension of perceived value derives from the feelings and emotions that the product or service generates in the buyer. Few studies have focused on the emotional dimension, so the identification of its dimensions is at an exploratory stage. The first studies into the emotional value dimension follow on from the IMP studies on B2B relationships in industrial markets with the interaction model (Metcalf, Frear and Krishnan, 1990; Sandström, 1992). A series of studies in industrial (Eggert and Ulaga, 2002; Ulaga and Eggert, 2003, 2006) and service markets (Sweeney and Soutar, 2001; Barnes, 2003) followed. These last perspectives, together with the findings of these studies enable identification of three factors: experience, personalized treatment and interpersonal relationships. Firstly, accumulated experience is a consequence of the exchange of sensorial stimuli, information and emotions between firms and customers (Schmitt 1999; Sweeney and Soltar 2001), replacing the traditional stimuli both in consumer markets (Holbrook and Hirschman 1982; Schmitt, 1999), and in industrial markets (Brown et al, 1995). Personalized treatment and interpersonal relationships derive from the literature that analyzes the psychological benefits (Gwinner, Gremler and Bitner 1998, Ford and McDowell, 1999; Barnes, 2003; Biggemann and Buttle, 2005) and the social benefits that establishing a relationship brings, whether at individual or business level. Thus for Henning-Thurau and Hansen (2000), personalized treatment is among the elements that customers value positively and continually in their relationships with firms. Price, Arnauld and Deibler (1995), and Henning-Thurau, Gwinner and Gremler (2002) also find that personalized treatment helps to reduce the feeling of anxiety and to generate a relaxed situation because customers know what they are going to receive in their dealings with the supplying firm. Finally, interpersonal relationships tie in closely with the two previous factors, experience and personalized treatment, and also help to generate pleasant feelings in the relationship with the supplying firm, and help to make the relationships more fluid and long lasting (Gwinner, Gremler and Bitner 1998; Price and Arnauld, 1999, HenningThurau, Gwinner and Gremler, 2002). Sweeney and Weeb (2002) also agree on this point, 
affirming that the perceptions of affinity, friendship, or feeling of familiarity in the other party help to strengthen the relationships between firms. The second hypothesis is therefore:

$\mathrm{H}_{3}$ : The emotional dimension of perceived value in an industrial market comprises experience, personalized treatment, and interpersonal relationships.

Finally, the social dimension of perceived value refers to the consequences of the purchase and consumption of a product or service for different target populations. This dimension includes the social perspective of the company, in other words, the importance of society's assessment of the company. In industrial markets, where the personal tools of marketing are essential, the image or the reputation of a firm is a key element in decision making. Lapierre (2000) defines social value as the image based on reputation and credibility and the social repercussions these have. In the same vein, Allee (2000) suggests that perceived value should incorporate elements as important as social citizenship and corporate identity. Nguyen and Leblanc (2001) coincide with Lapierre (2000) in identifying corporate reputation and social image as the determining factors of the social dimension. The social image conveyed, together with reputation, therefore emerge as the two factors underlying the social dimension (Sheth, Newman and Gross 1991a; Ganesan, 1994; Lapierre, 2000; Nguyen and Leblanc, 2001).

$\mathrm{H}_{4}$ : The social dimension of perceived value in an industrial market comprises reputation and the perceived social image.

\section{Research Method}

The essential aim of the study is to identify the dimensions of the perceived value of the relationships among firms in an industrial cluster, by developing a scale of measurement of the construct. To this end, we take into account the rational, emocional and social components of perceived value and its emotional and social components.

We chose The Spanish cluster of ceramic floor tile manufacturers because it was a special characteristics. Over the last 20 years it has developed a clear exporting component, where the constant investment has had as result continuous improvements in process and product technology, and more recently, in its relationships with its customers. And this tendency continues. The research included interviews with purchasing managers about the manufacturing firm's relationship with its main supplier of ceramic frits, enamels and colors, products. This supplier met the desired criteria of reliability and adequacy for both the 
products and the services offered, characteristics considered important for B2B (Lam et al. 2004). The justification of this choice lies in the fact that across all the firms, possibly the frequency of deliveries, together with the technical knowledge of the product, requires collaboration and a certain level of intensity of contact between supplier and manufacturer. The quality of the frits, enamels and ceramic colors these suppliers manufacturer, the constant research and innovations in their products, together with the performance of a permanent support and advice service throughout the useful life of the products they supply, confers upon them special characteristics that are not evident in other types of suppliers and making this type of relationship appropriate for the objectives of the study.

Two sources of information provide the material to design the measurement scales for the questionnaire, thus ensuring the questionnaire's internal validity. The two sources were the literature on the subject, for secondary sources of information, and in-depth interviews with 5 purchasing managers. Given the scarcity of studies on perceived value in the industrial market, the authors designed scales specifically for the objectives of the study, adapting them in some cases from the literature reviewed.

The questionnaire is structured in five major sections: functional value technical quality of product, functional value quality of service, functional value sacrifices, social value, and emotional value (table I).

\section{Table I here}

In accordance with the objectives of the study, we chose to gather information by means of a survey addressed to the purchasing managers, or by default to the general manager, of the tile manufacturing firm. The process involved three consecutive phases. The first phase consisted of a mailed questionnaire, together with a letter presenting the study and the motives for the research. We then made telephone contact to confirm that the managers had received the questionnaire and were willing to participate, following which the authors then sent out the questionnaire a second time, in this case by e-mail. However, in both cases very few managers responded, thus necessitating a third phase in which the research team conducted personal interviews in the firms that had not replied in the earlier phases. After making an appointment, an interviewer traveled to the firm's head office and administered the questionnaire by means of a personal interview with the purchasing manager. 
The population consists of all the Spanish ceramic tile industry member firms (245 firms, manufacturers of paving and wall tiles, and special pieces). Twenty-five (25) firms are suppliers of frits, enamels and ceramic colors.

The final sample comprised 101 observations, which for a confidence level of $95.5 \%(\mathrm{z}=2)$, and for an estimated proportion of $(\mathrm{p}=\mathrm{q}=0.5)$, gives a sample error of $\pm 7.84 \%$.

We tested the models with Structural Equation Models (SEM). In all the causal models obtained in the course of the data analysis, the authors applied the maximum likelihood estimation method (Jöreskog and Sörbom 1996b), taking as a reference the variancecovariance matrix calculated from the normalized data after application of the PRELIS normal scores procedure, which permits the joint normalization of the continuous variables being analyzed (Jöreskog and Sörbom 1996a). Moreover, in all these models the parameters that determine the relationships between the variables are always significant, with the associated t value higher than 1.96, and completely standardized.

Following all these considerations, we propose four hypotheses about perceived value dimensionality, previously described.

\section{Research Findings /Data Analysis}

The data analysis begins with a study of the dimensions, reliability and validity of the scales, using confirmatory factor analysis. A second order confirmatory factor analysis then determines the importance of each dimension.

All the analyses carried out in this section are adequate: the chi-squared probability is greater than 0.05, the statistics GFI and AGFI are close to unity; and RMSEA is close to zero (Hair, Anderson, Tatham and Black, 1999).

Moreover, the scales used are all reliable: the composite reliability coefficient is always above 0.63, reaching values in excess of 0.95 (Bagozzi and Yi 1988; Río, Iglesias and Vázquez 2000). Data also confirmed the convergent validity of the scales as the factor loadings are greater than 0.5, and each item contributes to the formation of only one factor (Bagozzi and Yi, 1988; Bagozzi, Yi and Phillips 1991; Steemkamp and Trijp, 1991). Likewise, results confirm the divergent validity of the scales: the confidence interval of the correlation between the dimensions obtained does not include unity (Bagozzi and Yi, 1988; Río, Iglesias and Vázquez 2000; Steemkamp and Trijp 1991). Tables II to VIII show these results.

\section{Functional value}


The hypothesis relating to functional value establishes the existence of sacrifice and benefit components. The literature review identified three quality-related dimensions in the positive component (quality of the product, quality of the firm's service and quality of the service employees provide), and a further three dimensions in the negative component (price, switching costs and convenience).

\section{Functional Value Product Quality}

The abovementioned confirmatory factor analysis determines the dimensionality, reliability and validity of the measurement scale of the functional value product quality (table II). This analysis reveals the existence of two dimensions: durable quality and technical quality. For the durable quality of the product, the highest factor loading derives from the item in which the reliability of the products purchased increases over time (0.77). For the technical quality of the product the highest factor loadings refer to the degree to which the supplier's products meet the technical specifications and to the fact that the supplying firm offers the best products; both factor loadings take a value of 0.64 .

Table II here

\section{Functional value firm's service quality}

Table III shows the individual analyses of the firm's service quality dimension. Three dimensions are of note. One is technical competence-tangibility, among whose items the highest factor loading is 0.83 corresponding in this case to creativity and innovation in products and services, expertise, and the main supplier's application of new technologies in the solution of problems. The second dimension detected is reliability. In this case, various items also appear with the same factor loading as above (0.83); these are speed and agility, keeping promises on dates and services, and doing things right first time. Lastly, the factors detected in the security dimension -accuracy of information, keeping promises and technical advice- present lower factor loadings than the previous ones.

Table III here

\section{Functional value employees' service quality}


The analysis of reliability and validity of the scale used to measure employees' service quality (table IV) shows that the two items with the highest factor loading (both with 0.92) are those referring to reliability and consistency, and employees' competence and professionalism, respectively.

Table IV here

\section{Functional value sacrifices}

Three dimensions become apparent from the factor analysis carried out for total sacrifices (table V): monetary sacrifices, non-monetary sacrifices of convenience, and the non-monetary sacrifice of switching costs. In the first dimension the highest factor loadings relate to the items "perception of a reasonable price" and "they offer the best discounts and payment conditions", the factor loading being 0.80 in both cases.

In the case of the convenience dimension, the highest factor loading relates to the importance of the number of visits made (0.65). As to switching costs, the two items forming this dimension have similar factor loadings ( 0.69 and 0.68 respectively); they refer to the effort and time that changing supplier would involve, and to the importance of continuing the relationship with the current supplier.

Table V here

\section{Social value}

Two dimensions of social value appear (table VI): social image and reputation. In the social image dimension, the two items with the highest factor loadings are the external recognition of one's social behavior (0.83) and internal ethical behavior (0.81). For the social reputation of the supplying firm, the item with the highest factor loading (0.92) refers to the credibility of the supplier and to its positive effect on the social image of the firm.

Table VI here

\section{Emotional value}


Three possible dimensions of emotional value emerge: experience, affective relationships, and personalized treatment or relationships. The joint confirmatory factor analysis of its components (table VII) shows that for the experience dimension the items with the highest factor loading are the ease of use of the products/services (0.72) and the perception of the supplier as an expert (0.70). In personalized treatment, physical recognition and remembering names present the same factor loading (0.70). Finally, the item with the highest factor loading appears in interpersonal relationships referring to the pleasantness of dealings with the employees of the supplying firm (0.74), followed by the supplier's pleasantness in general (0.70) and the development of bonds of friendship among the workers of the two firms $(0.70)$.

Table VII here

\section{Total perceived value}

Following the above confirmatory factor analyses for each of the components of the firm perceived value, the authors carried out a joint confirmatory factor analysis of its components, based on the weighted averages of the values obtained in the earlier analyses. Table VIII, corroborates the results of the earlier analyses, obtaining a model with good fit and a reliable scale with convergent and divergent validity, following the criteria indicated at the start of the data analysis.

Table VIII here

The functional value comprises, in order of importance of the factor loadings, the overall quality of the firm's service (0.84); the quality of the employees' service (0.76); the overall quality of the product $(0.76)$; convenience $(0,69)$; price $(0.62)$; and switching costs $(0.54)$. These results therefore confirm hypothesis $\mathrm{H}_{2}$.

Emotional value, for its part, consists of experience (0.89); interpersonal relationships (0.80); and personalized treatment (0.58), thus empirically confirming hypothesis $\mathrm{H}_{3}$.

Finally, social value comprises social image and reputation, both with the same explanatory factor loading (0.75), therefore confirming hypothesis $\mathrm{H}_{4}$.

The analysis of discriminant validity reveals correlation among the three variables, indicating the importance of each one of them in the management of perceived value in relationships 
with the industrial supplier (Gwinner, Gremler and Bitner 1998; Sweeney and Soutar 2001). The correlation between emotional value and functional value stands out with a value of 0.69 . The overall analysis of total perceived value continues with a second order factor analysis, including weighted measurements and the calculation of a variable to capture the overall value for inclusion in the general model. An overall latent variable for total perceived value results from this analysis. Figure 1 presents the results of this second order confirmatory factor analysis, and shows that three first order factors appear that include the same items as those obtained in the earlier analyses, thus determining that for each of these factors the factor loadings are similar to those considered individually in earlier stages.

Figure 1 here

Furthermore, a second order factor emerges that reflects total perceived value. This factor comprises functional value (0.91), emotional value (0.95), and social value (0.94). In interpreting the results, although all three have high factor loadings, emotional value has a slightly higher explanatory capacity in the formation of the overall customer perceived value. Nevertheless, the close parity among them establishes the need to consider them jointly in order to adequately interpret the customer perceived value, following Sweeney and Soutar (2001). That is to say, perceived value appears as a multidimensional construct in which the three dimensions interact and complement each other, in a balanced manner, and help to explain a complex construct, which adopts different roles and which customers can interpret in different ways, as authors such as Sheth, Newman and Gross (1991a); de Chernatony, Harris and Dall'Olmo (2000) and Sweeney and Soutar (2001) demonstrate.

The resulting model is adequate, since the chi-squared probability is greater than $0.05(0.052)$; the GFI (0.86) and AGFI (0.84) statistics are close to unity; and RMSEA (0.06) is close to zero (Hair, et al. 1999). Reliability is high: for both the first order factors and the second order factor, the overall reliability of the total perceived value is 0.96 (Bagozzi and Yi 1988). The model possesses convergent validity as all the factor loadings are higher than 0.5 , and also divergent validity for each of the dimensions of total perceived value, as their constituent items only form part of that factor and do not contribute to the formation of any other factor (Bagozzi and Yi 1988; Bagozzi, Yi and Phillips 1991; Steemkamp and Trijp 1991). 
Thus the findings also confirm $\mathrm{H}_{3}$, and the study empirically demonstrates that the value of a relationship from the perception of a customer firm comprises a functional, an emotional and a social dimension, which reinforces Sweeney and Soutar's (2001) claims in this respect.

\section{Discussion}

This study extends the analysis of the perceived value of the industrial relationships between a supplier and an industrial customer in a cluster. The theoretical analysis of the concept reveals perceived value to be a complex and multidimensional construct, comprising elements of a functional, emotional and social character, in which positive and negative elements occur simultaneously, with the individual or individuals with decision-making capacity in the customer firm making the relevant valuation. From this perspective, the perceived value construct is not directly observable. Consequently, a series of estimations of its component dimensions is essential.

One of the objectives of this study, therefore, was to draw up a scale of measurement of perceived value for industrial markets that will be valid for either of the two perceptions noted above: one comprising negative and positive connotations of a cognitive character, and a second multidimensional dimension. The proposed multidimensional model integrates the perceptions of value used in the literature, considering that significant behavioral and attitudinal differences occur in the relationships between a buyer and an industrial supplier, and in the generation of perceived value within that relationship.

The dimensional analysis led to 4 hypotheses, all of which the results confirmed. The empirical phase of this study verifies the existence of the three dimensions and their influence on the overall conception of perceived value. Traditional opinion held that decision-making in industrial markets followed basically rational or functional criteria. However, the results of the empirical study show the importance of emotional and social value in the formation of the perceived value of the relationship on the part of the customer firm. Undoubtedly, the fact that firms are organizations comprising individuals notably influences the existence of emotions, feelings and sensations that affect the final decisions of those with decision-making capacity in firms. Likewise the notable increase in the importance of the social perception of the firm and of its influence on financial results also confers social value with a more than significant role in the industrial purchaser's perception of higher value.

Nevertheless, certain details of the results require qualification. With regard to sacrifices, on analyzing the price, customer firms equate the purchase value of the product with the transaction value in accordance with the postulates of Monroe (1990) and Grewal et al. 
(1998). With respect to non-monetary sacrifices, the homogeneity in the factor loadings of the items analyzed shows the importance for the manufacturers of floor and wall tiles of their relationship with the supplier of frits, enamels and ceramic colors. The technological dependence that occurs in this relationship, on many occasions as a consequence of the greater innovation capacity of the supplier of frits, enamels and ceramic colors, leads to the situation where most innovations in ceramic products are a result of the developments in the supplier's laboratories. This situation exposes a weakness of manufacturing firms against their suppliers, as they leave an important part of the research, development and innovation in the hands of the supplier, making life easier for their own design departments, but weakening them at the same time. In this way, the manufacturer leaves decisions on the final design of the product that he or she will have to sell to the supplier of frits, enamels and ceramic colors.

The analysis of product quality confirms that technical quality is as important as the perception of the utility of the product over time. The customer firm's valuation in the present about the future benefits that the firm can obtain by using the product is decisive in its decision to purchase. If at the time of purchase the attributes of the product and the price are important, no less so are the firm's perception of use and the results obtained. Thus the results of this study confirm contributions such as Slater (1997) and Woodruff (1997).

In the valuation of the employees' service, the factors with a more technical profile, such as reliability, competence and professionalism, have greater explanatory loading on this variable. Factor loadings on these items are above those of other more behavioral factors such as accessibility and conduct. Therefore, although the human factor is important, in this study, customers value the professional and technical profile of their supplier's employees more highly than the behavior of the firm itself.

The results of the study show that in the two dimensions of social value considered, social image and reputation, the factors the customer values most highly are good social practices and credibility in general. In this situation adequate management of information becomes a key factor in business and social success (Nguyen and Leblanc, 2001). If the results of the study show that customer firms are sensitive to the social behavior of the supplier firm, but that its credibility is high, in this situation the supplier needs to know how to publicize its achievements in this field both internally and externally. The right presence in the media, together with careful transmission of information to its customers, become key factors for the success of the firm. 
The results obtained from the analysis of the dimensionality of emotional value provide evidence to support the claims of other authors like Gwinner, Gremler and Bitner (1998) on aspects such as familiarity, fraternization, friendship and personal recognition between employee and customer, which are some of the most highly valued factors in the creation of social benefits, particularly in situations where the interaction between customer and employee is intense, as is generally the case in industrial and services markets. In addition, authors such as Brown et al. (1995); Slater and Narver (2000); Sweeney and Soutar (2001) among others have already demonstrated the importance of experience. Experience permits the accumulation of information and knowledge that adequately managed and correctly applied, lend credibility, another of the factors highly valued in the study.

To a certain extent, the presence of the emotional and social component in the perception of value by the customer links in with the conception of relationship marketing understood as humanized marketing. In this context, commercial strategies based on intensive production processes, based in turn on the application of mass marketing, are giving way to a type of marketing with a more individualized application, grounded in research and the proper use of data bases, whose application permits personalized treatment, that is offering products and services on the customer's terms. This shift includes an attitude in the relationship based on the analysis of human values as determinants of the consumers' purchase processes, both for their indirect influence on prices through the need to satisfy the customers' desire for utility, and for their direct influence by satisfying their needs for self-expression, where the experience, from this perspective, once more becomes an important asset for firms.

\section{Managerial implications}

Traditionally, the general attitude to relationships in industrial markets was one of a mere rational exchange, due to the complexity of decision making in sometimes very large purchase agreements. However, the results of this study reveal that emotional and social values have considerable weight in this decision-making process, due mainly to the necessary conjugation of the dual objective of firms, those of an economic and business character and those of a human and personal character. The fact that firms are essentially organizations of people endows each one of them with features and characteristics that make them different from each other and, obviously, condition their final valuation in the decisions to purchase from their suppliers.

The identification of the emotional and social components in the decision-making processes of the firms in a cluster, and in the formation of the customer perceived value, should lead the 
managers of supplier firms to reconsider the need to develop a commercial policy in harmony with a social and human policy. The results of the empirical study underline the need to train personnel with the triple perspective proposed in the dimensions of perceived value, which will be of great importance in the near future.

Firms must therefore be capable of working in this three-way direction. At least the employees whose functions involve interrelationships with other firms should receive training in this perspective. This firstly, involves technical training on the product and the services that the firm offers. Employees must be aware of technical characteristics, use, installation and operation, among other aspects. Secondly, they should also receive human training, understood as skills in developing interpersonal relationships, social sensitivity, respect for people and integration in a working team. This training should also include fostering sensitivity to environmental and business ethics issues, how they can affect the negative image of the firm externally in these aspects and how to constantly work to improve this image. Thirdly, they should receive specific training in their specialty at work: the training that the person brings to the job through education and experience must go hand in hand with continuous training in how to incorporate and understand the new advances that are continually occurring in all fields. Finally, a thorough understanding of the firm's vision, mission, culture and values will enable employees to contextualize all they have learned within the sphere in which they apply this knowledge.

The managers of the floor and wall tile manufacturing firms should consider their technological and design dependence, and enhance their own design departments with the aim of differentiating themselves from their competitors. They cannot ignore the fact that one supplier sells to several manufacturers, so the possibility of similar designs coexisting at the same time in the market is a real threat. Ideas must emerge within firms as a sign of their creative capacity and of their personality, and as a sign of identity. Matching the taste of the markets is a sign of firms' skill in juggling innovation with acceptance.

\section{Limitations and and further research}

This research took place in the context of industrial relationships between two manufacturing firms, where one plays the role of supplier and the other that of industrial purchaser. Bearing this fact in mind, the conclusions are only relevant to this particular relationship, and not to other relationships in an industrial market, such as those between manufacturers and retailers. The constructs are applicable to a particular moment in time, although the analysis takes into account the course of the relationship up to that moment, and future situations arising as a 
consequence of the relationship. Nonetheless, any interpretation of the conclusions drawn must consider this condition, thus revealing the need for a longitudinal study of this model in future studies.

The study focuses on dyadic relationships from the purchaser's viewpoint, and consequently the purchaser was the person interviewed. This focus of analysis obviously limits the study in light of the fact that industrial relationships between two parties occur in the context of a network of relationships. Future lines of research should extend this study to relationship networks, analyzing as a first step the opinion of the supplier and then widening the analysis to the rest.

As this analysis considers a single type of industrial supplier, specifically the most important supplier for the firm, the conclusions of the study are not applicable to other relationships with these suppliers, and even less so to the general body of suppliers of the customer firm. Future studies should extend the initial phase to include all the suppliers in this category of products and services, and in a second phase, to all other suppliers.

More in-depth analysis could determine whether any factors exist other than those comprising the dimensions that appear in this study. It could beFurther research may consider whether the dimensions obtained are only applicable to the industry studied here, or whether analysis of other industries would reveal other dimensions alongside the existing ones. Analysis of the emotional and social elements in marketing is scant, and even more so in industrial markets.

\section{References}

Allee, V. (2000), "The Value Evolution", Journal of Intellectual Capital, Vol.1, № 1, pp.1732.

Anderson, J.C.; Jain, D.C. and Chintagunta, p.k. (1993), “Customer Value Assessment in Business Markets: A State-of-Practice Study”, Journal of Business to Business Marketing, Vol 1, No 1, pp. 3-30.

Bagozzi, R.P. and Yi, Y.(1988): “On the Evaluation of Structural Equation Models”. Journal of the Academy of Marketing Science, Vol. 16, No 1, pp. 74-94.

Bagozzi, R.P. Yi, Y. and Phillips, L.W. (1991): "Assessing construct validity in organizational research", Administrative Science Quarterly, Vol. 36, pp. № 3, pp. 421458.

Barnes, J.G. (2003), "Establishing Meaningful Customer Relationships: Why some Companies and Brands Mean More to Their Customers", Managing Service Quality, Vol. 13, № 3 , pp. 178-186. 
Bennet, R. and Gabriel, H. (2001), "Reputation, trust and supplier commitment: The case of shipping company/seaport relations", Journal of Business and Industrial Marketing, Vol. 16, $\mathrm{N}^{\mathrm{o}} 6$, pp. 424-438.

Berry, L.L.; Seider, K. and Gresham, L.G. (2002), "Understanding Service Convenience”, Journal of Marketing, Vol. 66, № 3, pp. 1-17.

Biggemann, S. and Buttle, F. (2005), "Conceptualising Business-to-Business Relationship Value”, 21st Annual IMP Conference Proceedings, electronic publication, pp. 1-10.

Bonner, J.M. and Calantote, R.J. (2005), "Buyer Attentiveness in Buyer-Seller Relationships", Industrial Marketing Management, Vol. 34, № 1, pp. 53-61.

Brennan, R., Turnbull, P. W., \& Wilson, D. T. (2003): "Dyadic adaptation in business markets", European Journal of Marketing, Vol. 37, nº 11, pp. 1636-1665.

Brown, J.R.; Lusch, R.F. and Nicholson, C.Y. (1995), "Power and Relationship Commitment: Their Impact on Marketing Channel Member Performance", Journal of Retailing, Vol. 74, No 4, pp. 363-392.

Cronin Jr, J.; Brady, M; and Hult, T. (2000), “Assessing the Effects of Quality, Value, and Customer Satisfaction on consumer Behavioural Intentions in Service Environments", Journal of Retailing, Vol. 76, № 2, pp. 193-218.

De Chernatony; L.; Harris, F. and Dall'Olmo Riley, F. (2000), ”Added Value: Its Nature, Roles and Sustainability", European Journal of Marketing, Vol. 34, № 1/2, pp. 39-56.

De Ruyter, J.K.; Wetzels, M.; Lemmink, J. and Mattson J. (1997), “The Dynamics of the Service Delivery Process: A Value-Based Approach", International Journal of Research in Marketing, Vol. 14, № 3 (July), pp. 231-243.

Eggert, A and Ulaga, W. (2002), "Customer Perceived Value: A Substitute for Satisfaction in Business Markets?", Journal of Business and Industrial Marketing, Vol. 17, № 2/3, pp. 107-118.

Flint, J. D. and Woodruff, R.B. (2001), “The Initiators of Changes in Customer's Desired Value: Results from a Theory Building Study”, Industrial Marketing Management, Vol. 30, No 4 (May), pp. 321-337.

Ford, D., D. and McDowell, R. (1999), "Managing Business Relationships by Analysing the Effects and Value of Different Actions", Industrial Marketing Management, Vol. 28, $\mathrm{N}^{\mathrm{o}}$ 5, pp. 429-442.

Ganesan, S. (1994): "Determinants of Long-Term Orientation in Buyer-Seller Orientation in Buyer-Seller Relationships”, Journal of Marketing, Vol 58, № 2 (April), pp. 1-19. 
Grewal D.; Monroe, K. and Krishnan, R. (1998)," The Effects of Price-Comparison Advertising on Buyers' Perceptions of Acquisition Value, Transaction Value, and Behavioral Intentions“, Journal of Marketing, Vol. 62, № 2 (April), pp. 46-59.

Gwinner, K.; Gremler, G. and Bitner, M.J., (1998), "Relational Benefits in Services Industries: The Consumer's Perspective", Journal of The Academy of Marketing Science, Vol. 26, No 2, pp. 101-114.

Hair, J.F.; Anderson, R.E.; Tatham, R.L. and Black, W. (1999), Multivariate Data Analysis, Fifth Edition: Prentice Hall International.

Hogan, J. E. (2001), "Expected Relationship Value: A Construct, a Methodology, and a Modeling Technique", Industrial Marketing Management, Vol. 30, № 4, pp. 339-35.

Henning-Thurau, Th. and Hansen, U. (2000), Relationship Marketing: Gaining Competitive Advantages Through Customer Satisfaction and Customer Retention, Springer-Verlag Berlin Heidelberg.

Henning-Thurau, Th.; Gwinner, K.P. and Gremler, D. D. (2002), “An Integration of Relational Benefits and Relationship Quality”, Journal of Service Research, Vol. 4, № 3, pp. $230-247$

Holbrook, M.B. and Hirschman, E.C. (1982), "The Experiential Aspects of Consumption: Consumer Fantasies, Feelings, and Fun”, Journal of Consumer Research, Vo. 9, ํㅡ 2 (September), pp. 132-140.

Jöreskog, K. G., and Sörbom, D. (1996a), LISREL 8: User's Reference Guide. Chicago: Scientific Software.

Jöreskog, K. G., and Sörbom, D. (1996b), PRELIS 2: User's Guide. Chicago: Scientific Software.

Kim, K., (2000), "On Inter-firm Power, Channel Climate, and Solidarity in Industrial Distributor-Supplier Dyads", Journal of the Academy of Marketing Science, Vol. 26, № 3, pp. 388-405.

Klemz, B.R. and Boshoff, C. (2001), "Environmental and Emotional Influences on Willingness-to-Buy in Small and Large Retailers", European Journal of Marketing, Vol. 35, Vol. 1/2, pp. 70-91.

Lam, S.; Shankar, V.; Erramilli, M.K. and Murthy, B. (2004), "Customer Value, Satisfaction, Loyalty, and Switching Costs: An Illustration from a Business-to Business Service Context", Journal of Academy of Marketing Science, Vol. 32 № 3 (Summer), pp. 293311. 
Lapierre, J. (2000), "Customer-perceived Value in Industrial Context", Journal of Business \& Industrial Marketing, Vol. 15, № 2/3, pp. 122-140.

Lindgreen, A. and Wynstra F. (2005), "Value in Business Markets: What do we Know? Where Are We Going?", Industrial Marketing Management Vol. 34, № 7, pp. 732-748.

Lovelock, C. H. (1991), Understanding Costs and Developing Pricing Strategies. In Services Marketing: Text, Cases and Readings. Ed. Prentice Hall International Editions, 2nd ed.

Lusch, R.F. and Brown, J.R. (1996), "Interdependency, Contracting, and Relational Behaviour in Marketing Channels", Journal of Marketing, Vol. 60, N 4 October, pp. 1938.

Metcalf, L.E., Frear, C.R. and Krishman, R. (1992): "Buyer-Seller Relationships. An Application of the IMP Interaction Model”, European Journal of Marketing, Vol. 26, N ${ }^{\circ}$ 2, pp. 27-46.

Monroe, K.B. (1990), Pricing: Making Profitable Decisions, New York: McGraw-Hill.

Nguyen, N. and LeBlanc, G. (2001), "Corporate Image and Corporate Reputation in Customers' Retention Decisions in Services", International Journal of Retailing and Consumer Service, Vol. 8, № 4 , pp. 227-236.

Nyer, P.U. (1997), “A Study of the Relationships between Cognitive Appraisals and Consumption Emotions”, Journal of the Academy of Marketing Science, Vol. 25, № 4, pp. 296-304.

Price, L.; Arnauld, E. and Deibler, S.L. (1995), “Consumers' emotional Responses to Service Encounters. The influence of the Service Provider", International Journal of Service Industry Management, Vol. 6, № 3, pp. 34-63.

Price, L. and Arnauld, E. (1999), "Commercial Friendship: Service Provider-Client Relationship in Context”, Journal of Marketing, Vol. 63, № 4, October, pp. 38-56.

Robinette, S.; Brand C. and Lenz, V. (2001), Emotion Marketing. The Hallmark Way of Winning Customer for Life, New York, McGraw-Hill.

Rust, T.R.; Zeithaml, V.A. and Lemon, K. N. (2000): “Driving Customer Equity: How Customer Lifetime Value Is Reshaping Corporate Strategy. New York: The Free Press

Sandström, M. (1992): The Culture Influence on International Business Relationships, in M. Forsgren, \& J. Johanson (Eds.), Managing Networks in International Business (pp. 4760), Philadelphia:Gordon \& Breach.

Schmitt, B.H. (1999), Experiential Marketing, The Free Press. 
Sharma, A; Krishnan, R and Grewal, D. (2001), "Value Creation in Markets. A Critical Area of Focus for Business-to-Business Markets”, Industrial Marketing Management, Vol. 30. pp. 391-402.

Sheth, J.N.; Newman, B.I. and Gross, B.L. (1991a), Consumption Values and Market Choice. Cincinnati, Ohio: South Western Publishing.

Sheth, J.N.; Newman, B.I. and Gross, B.L. (1991b), "Why We Buy What We Buy: A Theory of Consumption Values”, Journal of Business Research, Vol. 22 (March), pp. 159-170.

Simon, J and.Mandjak, T. (2004): "An Integrated Concep on the Value of Business Relationships", 20th Annual IMP Conference Proceedings, electronic publication, pp. 133.

Slater, S.F. (1997), "Developing a Customer Value-Based Theory of The Firm”, Journal of the Academy of Marketing Science, Vol. 25, № 2, pp. 162-167.

Slater, S.F. and Narver, J. (2000), "Intelligent Generation and Superior Customer Value", Journal of the Academy of Marketing Science, Vol. 28, Nº 1, pp. 121-127.

Spiteri, J.M. and Dion, P.A. (2004), "Customer value, overall satisfaction, end-user loyalty, and market performance in detail intensive industries", Industrial Marketing Management, Vol. 33, № 8, pp. 675-687.

Steemkamp, E.M. and Van Trijp, C.M. (1991), “The Use of LISREL in Validating Marketing Constructs”, International Journal of Research in Marketing, Vol. 8, pp. 283-299.

Sweeney, J.C.,Soutar, G. and Lester W. J. (1996). “Are Satisfaction and Dissonance the Same Construct? A Preliminary Analysis," Journal of Consumer Satisfaction, Dissatisfaction and Complaining Behavior,Vol. 9, pp. 138-143.

Sweeney, J.C., Soutar, G. and Johnson, L.W. (1999), “The Role of Perceived Risk in the Quality-Value Relationship: A Study in a Retail Environment”, Journal of Retailing, Vol. $75, \mathrm{~N}^{\mathrm{o}} 1$, pp. 77-105.

Sweeney, J.C., and Soutar, G (2001), "Consumer Perceived Value: The Development of Multiple Item Scale”, Journal of Retailing, Vol. 77, No 2, pp. 203-220.

Sweeney, J.C., and Webb, D. (2002), "Relationship Benefits: An Exploration of BuyerSupplier Dyads", Journal of Relationship Marketing, Vol. 1, № 2, pp. 77-92.

Ulaga, W. and Chacour, S. (2001), "Measuring Customer-Perceived Value in Business Markets: A Prerequisite for Marketing Strategy Development and Implementation", Industrial Marketing Management, Vol. 30, pp. 525-540. 
Ulaga, W., and Eggert, A. (2003): "Developing a Standard Scale of Relationship Value in Business Markets: Development of a Measurement Scale", 17th Annual IMP Conference Proceedings, electronic publication, pp. 1-38.

Ulaga, W., and Eggert, A. (2006), "Value -Based Differentiation in Business Relationships: Gaining and Sustaining Key Suppliers Status”, Journal of Marketing, Vol. 70, № 1 , January, pp. 119-136.

Woodruff, R. /1997), "Customer Value: The Next Source for Competitive Advantage", Journal of The Academy of Marketing Science, Vol. 25, No 2, pp.139-153. 


\section{ANNEX 1}

Table I. Scales of measurement of the dimensions of industrial perceived value

\begin{tabular}{|c|c|c|}
\hline Variable & Number of items on scale & References \\
\hline $\begin{array}{l}\text { Functional value } \\
\text { technical quality } \\
\text { of product }\end{array}$ & $\begin{array}{l}\text { Durable quality: } 3 \text { items } \\
\text { Technical quality: } 3 \text { items }\end{array}$ & $\begin{array}{l}\text { Lapierre (2000), Ulaga and Chacour } \\
\text { (2001), Ulaga and Eggert (2003); } \\
\text { Spiteri and Dion (2004) }\end{array}$ \\
\hline $\begin{array}{l}\text { Functional value } \\
\text { firm's quality of } \\
\text { service }\end{array}$ & $\begin{array}{l}\text { Tangibility and technical competence: } 7 \\
\text { items } \\
\text { Reliability: } 5 \text { items } \\
\text { Security: } 3 \text { items }\end{array}$ & $\begin{array}{l}\text { Cronin, Brady and Hult (2000), } \\
\text { Lapierre (2000). }\end{array}$ \\
\hline $\begin{array}{l}\text { Functional value } \\
\text { employees' quality } \\
\text { of service }\end{array}$ & Employees: 4 items & $\begin{array}{l}\text { Lapierre (2000), Cronin, Brady and } \\
\text { Hult (2000). }\end{array}$ \\
\hline $\begin{array}{l}\text { Functional value } \\
\text { Sacrifices }\end{array}$ & $\begin{array}{l}\text { Price: } 4 \text { items } \\
\text { Convenience: } 4 \text { items } \\
\text { Switching costs: } 2 \text { items }\end{array}$ & $\begin{array}{l}\text { Lapierre (2000), Sweeney and Soutar } \\
\text { (2001), Lusch and Brown (1996), } \\
\text { Jones, Mothersbaugh and Beatty } \\
\text { (2000 and 2002) }\end{array}$ \\
\hline Social value & $\begin{array}{l}\text { Social image: } 4 \text { items } \\
\text { Reputation: } 3 \text { items }\end{array}$ & $\begin{array}{l}\text { Lapierre (2000), Nguyen and } \\
\text { Leblanc (2001), Sweeney and Soutar } \\
\text { (2001) Bennet and Gabriel (2001). }\end{array}$ \\
\hline Emotional value & $\begin{array}{l}\text { Experience: } 5 \text { items } \\
\text { Personalized attention: } 2 \text { items } \\
\text { Interpersonal relationships: } 5 \text { items }\end{array}$ & $\begin{array}{l}\text { Henning-Thurau; Gwinner and } \\
\text { Gremler (2002); Jones, } \\
\text { Mothersbaugh and Beatty (2000 and } \\
\text { 2002), Kim (2000), Lapierre (2000), } \\
\text { Robinette, Brand and Lenz (2001), } \\
\text { Sweeney and Soutar (2001), }\end{array}$ \\
\hline
\end{tabular}

Table II. Confirmatory Factor Analysis of the functional value quality of product

\begin{tabular}{|l|l|}
\hline DURABLE QUALITY OF PRODUCT & FACTOR LOADINGS \\
\hline The reliability of the products purchased increases with the passage of time & 0.77 \\
\hline $\begin{array}{l}\text { The quality of the products acquired from the supplier increases with the passage of } \\
\text { time }\end{array}$ & 0.74 \\
\hline $\begin{array}{l}\text { The yield obtained over time with the products acquired is a determining factor in } \\
\text { acquiring them }\end{array}$ & 0.60 \\
\hline TECHNICAL QUALITY OF PRODUCT & FACTOR LOADINGS \\
\hline $\begin{array}{l}\text { The technical specifications of the supplier's products are adequate for our } \\
\text { requirements }\end{array}$ & 0.64 \\
\hline
\end{tabular}




\begin{tabular}{|c|c|}
\hline The supplier firm offers me the best products & 0.64 \\
\hline The products a & 0.62 \\
\hline \multicolumn{2}{|c|}{$\begin{array}{l}\text { FIT OF THE MODEL: Chi-Squared= 21.72; gl= 14; P-value }=0.0845 ; \text { RMSEA=0.074; GFI= 0.93; AGFI= } \\
0.90\end{array}$} \\
\hline \multicolumn{2}{|c|}{$\begin{array}{l}\text { COMPOSITE RELIABILITY: Composite reliability of quality associated with passage of time }=0.7480 \text {; } \\
\text { Composite reliability of technical quality }=0.6638 \text {; Overall composite reliability }=0.8287\end{array}$} \\
\hline \multicolumn{2}{|c|}{$\begin{array}{l}\text { DISCRIMINANT VALIDITY (correlation between factors and in brackets the confidence interval of the } \\
\text { correlation): } 0.84(0.70-0.97)\end{array}$} \\
\hline
\end{tabular}

Table III. Confirmatory factor analysis of the functional value firm's service quality

\begin{tabular}{|c|c|}
\hline TANGIBILITY - TECHNICAL COMPETENCE & FACTOR LOADINGS \\
\hline $\begin{array}{l}\text { Our main supplier is very creative and innovative in the products and services } \\
\text { offered }\end{array}$ & 0.83 \\
\hline Our main supplier stands out for its special expertise in its activity in the industry & 0.83 \\
\hline $\begin{array}{l}\text { Our main supplier stands out for the way it uses new technology to generate } \\
\text { solutions }\end{array}$ & 0.83 \\
\hline $\begin{array}{l}\text { Our main supplier stands out for its capacity to provide systematic solutions in } \\
\text { response to our problems }\end{array}$ & 0.77 \\
\hline $\begin{array}{l}\text { Our main supplier stands out for its capacity to demonstrate wide knowledge of the } \\
\text { processes of our business }\end{array}$ & 0.74 \\
\hline $\begin{array}{l}\text { In general, the appearance of our supplier's physical installations and employees is } \\
\text { nice and clean }\end{array}$ & 0.64 \\
\hline In general, in our main supplier they strive to understand and attend to our needs & 0.64 \\
\hline RELIABILITY & FACTOR LOADINGS \\
\hline Our main supplier offers us fast and flexible service & 0.83 \\
\hline Our main supplier stands out for its skill in doing things right first time & 0.83 \\
\hline $\begin{array}{l}\text { Our main supplier scrupulously fulfils the delivery dates of orders or the } \\
\text { performance of the services agreed }\end{array}$ & 0.83 \\
\hline Our main supplier's invoices are accurate and clear & 0.61 \\
\hline Our main supplier knows how to deal with our complaints & 0.58 \\
\hline SECURITY & FACTOR LOADINGS \\
\hline For our firm the accuracy of the information from our supplier is very important & 0.77 \\
\hline For our firm the fulfilment of the promises made by the supplier is very important & 0.77 \\
\hline $\begin{array}{l}\text { For our firm the technical advice offered by the supplier for the management of our } \\
\text { business is very important }\end{array}$ & 0.74 \\
\hline \multicolumn{2}{|c|}{$\begin{array}{l}\text { FIT OF THE MODEL: Chi-Squared }=124.18 ; \mathrm{gl}=100 ; \text { P-value }=0.0510 ; \text { RMSEA = 0.049; GFI= 0.86; } \\
\text { AGFI }=0.83\end{array}$} \\
\hline
\end{tabular}


COMPOSITE RELIABILITY: Composite reliability of tangibility- Technical comp. = 0.9037; Composite reliability of reliability $=0.8581$; Composite reliability of security $=0.8037$; Reliability of total quality of service $=0.9512$

DISCRIMINANT VALIDITY (correlation between factors and in brackets the confidence interval of the correlation):

Tangib- technical comp. $\leftrightarrow$ Reliability: 0.74 (0.57-0.93)

Tangib- technical comp. $\leftrightarrow$ Security: 0.54 (0.40-0.68)

Reliability $\leftrightarrow$ Security: 0.35 (0.21-0.49)

Table IV. Confirmatory factor analysis of employees

\begin{tabular}{|l|l|}
\hline EMPLOYEES' SERVICE QUALITY & FACTOR \\
\hline $\begin{array}{l}\text { In general, the employees of our main supplier firm offer me a reliable and consistent } \\
\text { service }\end{array}$ & 0.92 \\
\hline In general, the employees of our main supplier firm are competent and professional \\
\hline $\begin{array}{l}\text { In general, the employees of our main supplier firm are accessible and it is easy to } \\
\text { contact them }\end{array}$ & 0.92 \\
\hline In general, the employees of our main supplier firm are polite and respectful & 0.65 \\
\hline \hline FIT OF THE MODEL: Chi-Squared=12.35; gl=7; P-value=0.0895; RMSEA=0.087; GFI=0.94; AGFI=0.91 \\
\hline COMPOSITE RELIABILITY: 0.8828
\end{tabular}

Table V. Confirmatory factor analysis of total sacrifices

\begin{tabular}{|l|l|}
\hline MONETARY SACRIFICE & FACTOR \\
\hline Our main supplier has a reasonable price & 0.80 \\
\hline The main supplier firm offers us the best discounts and conditions of payment & 0.80 \\
\hline It gives good value for money & 0.55 \\
\hline $\begin{array}{l}\text { The price offered is influenced by market competition } \\
\text { (time, effort, energy) }\end{array}$ & 0.55 \\
\hline $\begin{array}{l}\text { The number of visits or meetings that our employees have with the employees of the main } \\
\text { supplier are important for the good development of the relationships between the two } \\
\text { parties }\end{array}$ & 0.65 \\
\hline $\begin{array}{l}\text { The effort of negotiation with the employees of the supplier to reach an agreement is } \\
\text { appropriate }\end{array}$ & 0.60 \\
\hline $\begin{array}{l}\text { The time and effort invested in training some or all of our employees in the products and } \\
\text { services of the main supplier firm is appropriate }\end{array}$ & 0.60 \\
\hline \begin{tabular}{l} 
The main supplier is able to offer us the services required or the products desired whenever \\
\hline
\end{tabular} & 0.60 \\
\hline
\end{tabular}




\begin{tabular}{|l|l|}
\hline we need them & FACTOR \\
\hline NON-MONETARY SACRIFICE -SWITCHING COSTS & LOADINGS \\
\hline $\begin{array}{l}\text { Changing our main supplier would involve considerable time and effort for our firm due to } \\
\text { the need to adjust products and services }\end{array}$ & 0.69 \\
\hline For our firm it is very important to continue the relationship with this supplier & 0.68 \\
\hline \hline $\begin{array}{l}\text { FIT OF THE MODEL: Chi-Squared= 58.62; gl= 44; P-value= } 0.0690 ; \text { RMSEA= } 0.058 ; \text { GFI= } 0.90 ; \text { AGFI= } 0.88 \\
\text { COMPOSITE RELIABILITY: Composite reliability of price }=0.7780 ; \text { Composite reliability of convenience }= \\
0.7060 ; \text { Composite reliability of switching costs }=0.6391 ; \text { Overall composite reliability of sacrifices }=0.8829\end{array}$ \\
\hline $\begin{array}{l}\text { DISCRIMINANT VALIDITY (correlation between factors and in brackets the confidence interval of the } \\
\text { correlation): } \\
\text { Price } \leftrightarrow \text { Convenience: } 0.54(0.44-0.64) \\
\text { Price } \leftrightarrow \text { Switching costs: } 0.26(0.12-0.40) \\
\text { Convenience } \leftrightarrow \text { Switching costs: } 0.68(0.58-0.78)\end{array}$ \\
\hline
\end{tabular}

Table VI. Confirmatory factor analysis of total social value

\begin{tabular}{|l|l|}
\hline SOCIAL IMAGE & FACTOR LOADINGS \\
\hline Our main supplier has a reputation for good social behavior & 0.83 \\
\hline $\begin{array}{l}\text { I consider that our main supplier behaves ethically towards its customers and } \\
\text { employees }\end{array}$ & 0.81 \\
\hline $\begin{array}{l}\text { Generally, I read and pay attention to all the information that our main supplier sends } \\
\text { me }\end{array}$ & 0.56 \\
\hline $\begin{array}{l}\text { Our supplying firm participates actively in social events } \\
\text { REPUTATION }\end{array}$ & 0.55 \\
\hline The general credibility of our main supplier helps to improve the image of our firm & 0.92 \\
\hline $\begin{array}{l}\text { The general reputation of our main supplier fits with the image of our firm that we } \\
\text { want to present }\end{array}$ & 0.79 \\
\hline The relationship with our main supplier improves the social perception of our firm & 0.77 \\
\hline \hline \begin{tabular}{l} 
FIT OF THE MODEL: Chi-Squared= 19.74; gl= 14; P-value= 0.1386; RMSEA=0.064; GFI=0.95; AGFI=0.89 \\
\hline $\begin{array}{l}\text { COMPOSITE RELIABILITY: Composite reliability of factor 1 =0.8103; Composite reliability of factor } 2 \\
\text { =0.8674; Total composite reliability =0.9017 }\end{array}$
\end{tabular} \\
\hline $\begin{array}{l}\text { DISCRIMINANT VALIDITY (correlation between factors and in brackets the confidence interval of } \\
\text { correlation): 0.59 (0.41-077) }\end{array}$ \\
\hline
\end{tabular}

Table VII. Confirmatory factor analysis of total emotional value 


\begin{tabular}{|c|c|}
\hline EXPERIENCE & $\begin{array}{l}\text { FACTOR } \\
\text { LOADINGS }\end{array}$ \\
\hline $\begin{array}{l}\text { The ease of use of the products/services of our main supplier favors the desire to use } \\
\text { them }\end{array}$ & 0.72 \\
\hline The experience with the supplier seems to us a determining factor in the relationship & 0.61 \\
\hline Our supplier, in general, knows in advance what we need & 0.51 \\
\hline Our main supplier's experience enables it to offer the best advice & 0.61 \\
\hline This supplier is an expert in its field & 0.70 \\
\hline PERSONALIZED ATTENTION & \\
\hline The employees of our supplier recognize me when I deal with them & 0.70 \\
\hline In the supplier firm they know my name & 0.70 \\
\hline INTERPERSONAL RELATIONSHIPS & \\
\hline Relationships with our main supplier are pleasant & 0.70 \\
\hline $\begin{array}{l}\text { Bonds of friendship have developed between the main supplier's employees and ours } \\
\text { when they visit us or vice versa }\end{array}$ & 0.70 \\
\hline Relationships and dealings with our main supplier's employees are pleasant & 0.74 \\
\hline $\begin{array}{l}\text { In general, interacting with our main supplier produces positive feelings that I don't } \\
\text { think we would have if we had no contact with it }\end{array}$ & 0.62 \\
\hline The evolution of the relationship with our supplier seems positive & 0.70 \\
\hline \multicolumn{2}{|c|}{ FIT OF THE MODEL: Chi-Squared= 86.26; gl= 68; P-value=0.06674; RMSEA=0.052; GFI=0.87; AGFI= 0.86} \\
\hline \multicolumn{2}{|c|}{$\begin{array}{l}\text { COMPOSITE RELIABILITY: Composite reliability of experience }=0.7521 \text {; Composite reliability of } \\
\text { personalised attention }=0.6577 \text {; Composite reliability of interpersonal relationships }=0.8238 \text {; Overall } \\
\text { composite reliability of total emotional value }=0.8684\end{array}$} \\
\hline \multicolumn{2}{|c|}{$\begin{array}{l}\text { DISCRIMINANT VALIDITY (correlation between factors and in brackets the confidence interval of the } \\
\text { correlation): }\end{array}$} \\
\hline \multicolumn{2}{|l|}{ Experience $\leftrightarrow$ personalised attention: $0.27(0.15-0.39)$} \\
\hline \multicolumn{2}{|l|}{ Experience $\leftrightarrow$ interpersonal Relationships: $0.39(0.27-0.51)$} \\
\hline personalised attention $\leftrightarrow$ interpersonal Relationships: $0.39(0.27-0.51)$ & \\
\hline
\end{tabular}

Table VIII. Confirmatory factor analysis of total perceived value

\begin{tabular}{|l|l|}
\hline TOTAL PERCEIVED VALUE & FACTOR LOADINGS \\
\hline Functional Value & 0.62 \\
\hline Price (SACM) & 0.69 \\
\hline Convenience (SACONV) & 0.54 \\
\hline Switching costs (SACC) & 0.76 \\
\hline Product quality (BFCP) & 0.76 \\
\hline Quality of employees (BFCPEMPL)
\end{tabular}


Multidimensional perspective of perceived value in industrial clusters

\begin{tabular}{|c|c|}
\hline Firm's service quality (BFCEMP) & 0.84 \\
\hline \multicolumn{2}{|l|}{ Social Value } \\
\hline Social image (VSIMG) & 0.75 \\
\hline Reputation (VSREP) & 0.75 \\
\hline \multicolumn{2}{|l|}{ Emotional Value } \\
\hline Experience (VEEXP) & 0.89 \\
\hline Personalised attention (VETP) & 0.58 \\
\hline Interpersonal relations (VERI) & 0.80 \\
\hline \multicolumn{2}{|c|}{$\begin{array}{l}\text { FIT OF THE MODEL: } \text { Chi-Squared }=72.88 ; \mathrm{gl}=55 ; \text { P-value }=0.05361 ; \text { RMSEA }=0.057 ; \text { GFI }=0.88 ; \text { AGFI= } \\
0.86\end{array}$} \\
\hline \multicolumn{2}{|c|}{$\begin{array}{l}\text { COMPOSITE RELIABILITY: Composite reliability of emotional value }=0.8556 \text {; Composite reliability of social } \\
\text { value }=0.7188 ; \text { Composite reliability of emotional value }=0.8086 \text {; overall composite Reliability of perceived } \\
\text { value }=0.9260\end{array}$} \\
\hline \multicolumn{2}{|c|}{$\begin{array}{l}\text { DISCRIMINANT VALIDITY (correlation between the factors and in brackets the confidence interval of the } \\
\text { correlation): }\end{array}$} \\
\hline \multicolumn{2}{|c|}{ Functional value $\leftrightarrow$ Social value: $0.55(0.35-0.75)$} \\
\hline \multicolumn{2}{|l|}{ Functional value $\leftrightarrow$ Emotional value: $0.69(0.47-0.91)$} \\
\hline Social value $\leftrightarrow$ Emotional value: $0.55(0.35-0.75)$ & \\
\hline
\end{tabular}


Figure 1. Second order confirmatory factor analysis of the total perceived value of the firm

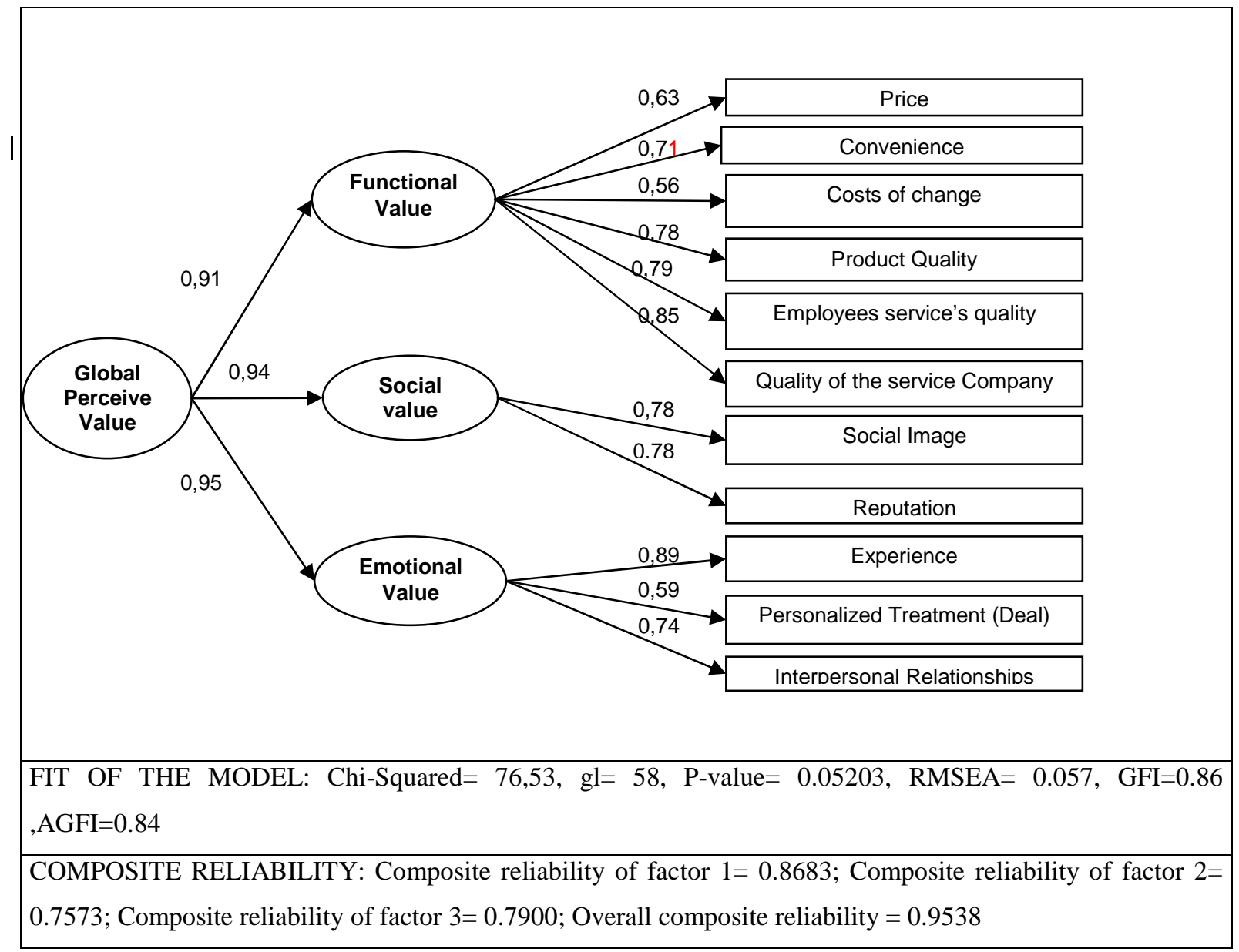

